\title{
From conciliar ecumenism to transformative receptive ecumenism
}

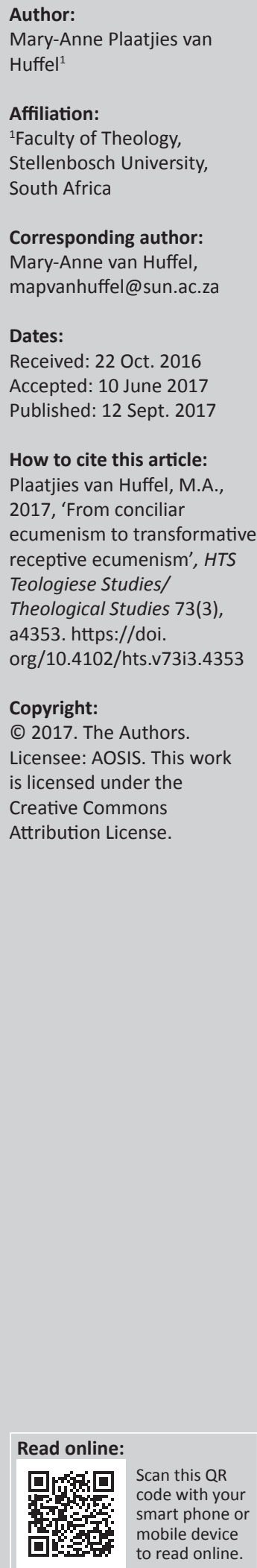

\begin{abstract}
This article attends to ecumenicity as the second reformation. The ecumenical organisations and agencies hugely influenced the theological praxis and reflection of the church during the past century. The First World Council of Churches (WCC) Assembly in Amsterdam, the Netherlands, has been described as the most significant event in church history since the Reformation during the past decade. We saw the emergence of two initiatives that are going to influence ecumenical theology and practice in future, namely the Receptive Ecumenism and Catholic Learning research project, based in Durham, United Kingdom, and the International Theological Colloquium for Transformative Ecumenism of the WCC. Both initiatives constitute a fresh approach in methodology to ecumenical theology and practice. Attention will be given in this article to conciliar ecumenism, receptive ecumenism, transformative ecumenism and its implications for the development of an African transformative receptive ecumenism. In doing so, we should take cognisance of what Küng says about a confessionalist ghetto mentality: 'We must avoid a confessionalistic ghetto mentality. Instead we should espouse an ecumenical vision that takes into consideration the world religions as well as contemporary ideologies: as much tolerance as possible toward those things outside the Church, toward the religious in general, and the human in general, and the development of that which is specifically Christian belong together!'
\end{abstract}

\section{Introduction}

Currently, it seems as if the ecumenical movement is in deep crisis. Sarah Timmer (2014) indicated in her groundbreaking dissertation, Ecumenism and Justification: Roman Catholic and Reformed Doctrine in Contemporary Context, that in the 1960s Hans Küng expressed what he believed was a widely held growing impatience with the lack of real change in the Church in spite of the work of the ecumenical movement. Cardinal Walter Kasper, President of the Pontifical Council for Promoting Church Unity (2001-2010), build further on the notion of an ecumenical winter. He made reference to 'a spirit of resignation' or 'a phase of hibernation' in current ecumenism. He categorically states that the ecumenical enthusiasm of the decade after the Second Vatican Council has gone, and many people are disappointed and ask: 'Does it still make sense to engage in this issue? Can we ever make substantial progress and reach the goal of visible unity? Is this not an unrealistic dream and a useless utopia? Is ecumenism perhaps a dead relic of the Second Vatican Council?' (Kasper 2011:13). The Second Vatican Council (1962-65) declared that the restoration of unity among all Christians is one of the principal concerns of the Council. The Council furthermore added that the division among Christians contradicts the will of Christ, scandalizes the world, and damages that most holy cause, the preaching of the Gospel to every creature' (Unitatis Redintegratio 1964). According to Kasper, the main difference between Catholics and Protestants is ecclesiology, that is, the question of what is the Church. Because Catholics and Protestants have different conceptions of the Church, it leads to a different conception of what church unity and the aims of the ecumenical movement entail (Kasper 2011:24). Cardinal Kasper's presumption is that receptive ecumenism and the call to Catholic learning will contribute to a new start and hopefully also a new spring within the ecumenical movement (Timmer 2014).

\section{Roman Catholic Church and the ecumenical council}

The conciliar movement was a Christian reform movement in the Roman Catholic Church during the 14th and 15th centuries. The conciliar movement, an attempt to modify and limit papal control over the Church by means of general councils, was sparked off by the papal election of 1378, when, following the return of the papacy from Avignon to Rome, French cardinals rejected the election of the Italian Urban VI, on canonical grounds, and elected Clement VII as anti-pope (Moss 2015). The movement was a response to growing centralisation of church administration 
and justice and to the desire for church reform. The movement was led mostly by the French and Germans. It evoked little response in Italy. According to Antony Black, conciliarism was a moderate programme in comparison with the aspirations of men like Marsilius of Padua (1270-1342) who among others denounced the papacy (Black 1988). For example, Marsilius of Padua collaborated with the Averroist philosopher Jean de Jandun on Defensor pacis [Defender of the Peace] in 1324, which laid out an elaborate theory of government by popular sovereignty and challenged the authority of the Pope and clergy over secular affairs. Marsilius' premise in Defensor pacis is that the state should run its own affairs without interference from the church (Marsilius of Padua 2016).

The Fifth Council of the Lateran (1512-1517) failed to address church reform appropriately. According to Küng (1963:9), the reform of the Church was set before the assembly as its principal task in the opening speech by the General of the Augustinians, Egidius of Viterbo (Martin Luther's superior general). Six months after the Fifth Council of the Lateran conclusion, the Lutheran Reformation broke out. The Council of Trent (Latin: Concilium Tridentinum), held between 1545 and 1563 in Trento (Trent) and Bologna, northern Italy, had been prompted by the Protestant Reformation and can be described as the Counter-Reformation. The Council of Trent among other matters addressed church reform and repudiated Protestantism, defined the role and canon of Scripture and the seven sacraments and strengthened clerical discipline and education (Ecumenical Council World Heritage Encyclopedia 2016).

The First Council of the Vatican (1870) defined the pope's primacy in church governance and his infallibility, repudiated rationalism, materialism and atheism, addressed revelation, interpretation of scripture and the relationship of faith and reason. The Second Council of the Vatican (1962-1965) addressed pastoral and disciplinary issues dealing with the Church and its relation to the modern world, including liturgy and ecumenism. The Second Vatican Council led the Catholic Church to enter into the mainstream of modern ecumenism. According to Küng, even the Catholic Church has to apply to herself the description of ecclesia semper reformanda, the Church that always has to be reformed (Küng1963:24). He envisaged a reformed and renewed Catholic Church, ecclesia catholica reformata. According to Küng, the ecclesia is indeed a concilium oecumenicum. Küng's view is that the whole ekklesia is the mysterious gathering of those who believe in Christ (p. 51). According to Black (1988:573), conciliarism reflected a shift in religious sentiment from universality to nationality and a sense that religious matters could legitimately be debated by the clergy. A move from papal centralisation to the decentralisation of power to secular rulers and nation states therefore took place.

According to Kasper, the ecumenical developments of the 20th century were valued in the Catholic Church long before the Second Vatican Council (1962-65) officially took part in the movement (Kasper 2005). In the first half of the century, theologians such as Paul Couturier, Yves Congar, Jan Willebrands, Hans Urs von Balthasar, Karl Adam and many others, following in the footsteps of Johann Adam Möhler and John Henry Newman, paved the way for the Council's Decree Unitatis Redintegratio, in which the Council affirms that the restoration of the unity among all Christians is one of its principal concerns (p. 1).

The Edinburgh World Missionary Conference in 1910 inspired the birth of the modern ecumenical movement. According to Kasper, this was probably one of the first unofficial contacts between the Catholic Church and the early beginnings of the ecumenical movement (Kasper 2005:1). Bishop Geremia Bonomelli from Cremona (18311914) sent a personal message to the World Missionary Conference in Edinburgh Missionary Conference in 1910. On 02 November 1914, Robert Gardner, Secretary of the Commission of the Episcopal Church US, wrote to the Secretary of State Cardinal Gaspari asking for an audience with the Pope for the purpose of discussing the proposed Conference of all Christian Communions to discuss 'Faith and Order' questions. This audience was granted and in May 1919, a delegation of five Episcopalians visited Pope Benedict XV (1914-1922). When the first World Conference on Faith and Order, growing out of the Edinburg conference, took place in Lausanne, Switzerland, in 1927 the Catholic Church was not ready to send any official delegates. The World Conference on Faith and Order involved men and women from 108 different churches, including many Protestant, Old Catholic, and Orthodox churches, and its aim was to discuss matters more theological and practical than missionary. Only an Instruction of the Holy Office issued on 20 December 1949 helped to create a more positive attitude towards the participation of Catholics in ecumenical gatherings. Four Catholic observers therefore participated in the World Council of Churches (WCC) Assembly of New Delhi in 1961.

The Second Vatican Council created an atmosphere which led the Catholic Church to entering the mainstream of modern ecumenism (Kasper 2005:2). In 1960, Pope John XXIII established the 'Secretariat for Promoting Christian Unity'. One of the first tasks of the Secretariat was to advise the Pope on how to proceed in inviting observers from other Churches and Ecclesial Communities, as well as representatives of ecumenical bodies. In 1962, the Secretariat was placed on the same level as other conciliar commissions, and thus it was responsible for preparing and presenting to the Council the documents on ecumenism (Unitatis Redintegratio), on nonChristian religions (Nostra Aetate), on religious liberty (Dignitatis Humanae) and, together with the doctrinal commission, the Dogmatic Constitution on Divine Revelation (Dei Verbum). Pope Benedict XVI (2005-2013) immediately after his election reaffirmed the same commitment in the following words:

Following in the footsteps of my predecessors, in particular Paul VI and John Paul II, I feel intensely the need to affirm again the irreversible commitment, assumed by the Second Vatican Council and continued over the last years, thanks also to the 
action of the Pontifical Council for Promoting Christian Unity. ${ }^{1}$ (Kasper 2005:1)

Kasper cautions us to bear in mind the changing ecumenical scene of the 21st century. According to Kasper, on the global level on the one side unions and alliances, a huge number of bilateral and multilateral ecumenical consensus or convergence documents are being observed while on the other side, tensions and even new divisions, often because ethical questions, are being witnessed (Kasper 2005:3). Regarding the future of ecumenism, Kasper (2005) said the following:

At the beginning of the 21st century, the ecumenical movement needs a revitalised ecumenical vision, a renewed spirit and a new commitment by all partners. This does not mean devising unrealistic utopias of the future. Instead of staring at the impossible, and chafing against it, we need to live the already given communio, and do what is possible today. This is more than we actually normally do. By advancing in this realistic way, step by step, we may hope that, with the help of God's Spirit who is always ready with surprises, we will find the way towards a common future. (p. 3)

According to Kasper, the foundation of the ecumenical movement in the 21st century is not a question of a mere emotional family feeling or a vague humanitarianism (Kasper 2005:3). The cornerstone of the movement is Jesus Christ (cf. Matt 21:42). Kasper highlights that the continuation of the dialogue on baptism and the mutual recognition of baptism, initiated in 1982 with the Lima documents on Baptism, Eucharist and Ministry, is fundamental for future ecumenical relations. He underscores on the one side the importance that the ecumenical movement should have a shared vision and goal and on the other side the Catholic understanding of unity, namely understood as full communion in faith, sacraments and Church ministry. The Catholic understanding of unity is not to be confounded with uniformity. Communion finds expression in the Roman Catholic Church in the confession of faith, the celebration of the sacraments, the exercise of the ministry and the reception of previous councils. In this sense, a council is a means of enabling a local church, a certain group of local churches, or all the local churches in communion with the bishop of Rome to express the communion of the Catholic Church (Ecumenical Collaboration at Regional, National and Local Levels 1975). Kasper, however, understands that unity as communion implies unity in diversity and diversity in unity (Kasper 2005:3). According to Kasper, plurality should not be identified with contradictory doctrinal pluralism or indifferentism about our respective confessional positions. Dialogue, according to Kasper, presupposes partners who have their own clear identity; only then can they appreciate another and different identity and enter into a meaningful and fruitful dialogue. According to Kasper, the soul and the heart of the ecumenical movement is spiritual ecumenism. When we speak of spiritual ecumenism, we do not use this concept - which is unfortunately overused -

1.Address of Benedict XVI delivered on Monday in the Clementine Hall of the Apostolic Palace, when meeting with representatives of other religions and Christian confessions who came to Rome for the Pope's inauguration. Vatican City, April 26, 2005 (Zenit.org). to mean a spirituality that is vague, weak, merely sentimental, irrational and subjective, that does not take into account the objective Church tradition, or even ignores it. It does not mean any spirit but the Spirit of Jesus Christ, who confesses 'Jesus is the Lord' (1 Cor 12:3). According to Kasper, there will not be a new ecumenical enthusiasm without a renewed missionary spirit and theology.

Kasper rightly deduced that ecumenical activities should be grounded in spiritual ecumenism; otherwise, it will very soon become a soulless routine. He furthermore states that mere ecumenical activism becomes a soulless bureaucracy and is destined to exhaust itself. His premises is that mere academic debate among experts, no matter how important it may be, escapes the 'normal' faithful and touches only the margin of their hearts and lives. Kasper also perceives the blood of so many martyrs of so many churches in the 20th century as the seed for unity of the churches in the 21st century. Lastly, Kasper emphasises practical ecumenism (Kasper 2005:5). He perceives the unity of the Church not as a goal in itself. Rather he understands the unity of the Church as an instrument, sign and anticipation of the unity of all humankind. According to Kasper, the universal context of the commitment for the unity of the Church has further implications for social and political diakonia, practical witness, and for the dignity of the human person and for human rights, for the sanctity of life, family values, education, justice and peace, healthcare, the preservation of creation and last but not least interreligious dialogue.

\section{Ecumenical developments of the 20th century}

According to Dr Samuel Kobia, the formation of the WCC as a culmination of several ecumenical movements is arguably the most significant development in ecumenical history in the second half of the 20th century (Kobia 2005). The first assembly included delegates from 147 different churches from the Orthodox, Anglican and Protestant traditions. Ever since its foundation in 1948, the WCC, in Amsterdam, the Netherlands, has spoken out for and intervened in the interest of justice and peace (Wainwright 1977).

According to Todor Sabev, of the Bulgarian Orthodox Church, deputy general secretary of the WCC, the global ecumenical movement brought to the fore basic issues of councils and conciliarity, catholicity and sobornost (Sabev 1993). Todor Sabev's presupposition is that many theologians in Slavic and other Orthodox churches have seen the concept of sobomost as a promising approach to the conciliar process. He sees unity, catholicity and conciliarity as the essence of the church's being. Sabev's premise is therefore that the theology of sobomost should be explored anew as a theological basis and ecumenical tool for churches growing together in a conciliar process (p. 261).

In the ninth century, St Cyril and St Methodius - the great apostles of the Slavs - and their disciples translated the Greek 
words for 'Catholic church' in the Nicene-Constantinopolitan Creed as subornaia tsruki/tsrukv. In the Slavic language of the time, the adjective suborna (ia) meant 'conciliar' or 'synodal'. It was derived from the noun subor - council, church - and was related to the verbs subrati and beru - 'gather', 'gathering', 'bringing and assembling together'. These terms preserved their connotations in church Slavonic and modern Russian: sobornaia tcerkov, sobor, sobirati, brat. According to Sabev, the concept of conciliarity has been used in translating and interpreting 'sobornost' in order to challenge the identification of sobornost with catholicity and to articulate a new commitment to conciliar life (Sabev 1993:262). Conciliarity therefore refers accordingly, to Sabev, to the coming together of Christians with their particular charisms and ministries to express and to build up communion, to serve the body of Christ through common prayer and Eucharistic celebration, to share concerns and to seek counsel and make decisions on major issues. Conciliarity also refers to the consensus itself that is reached at church assemblies, councils and synods.

The conciliar life has its roots in the history of the ancient church (Matt 18:20; Acts 1:15-26; Acts 6:1-6; Acts 15:1-30; Gal $2: 1-14)$. Sobomost is a vision of the church as a great 'council', gathered from all over the world by the Holy Spirit. It is the 'principle' of spiritual Christian unity and communion. The councils were instruments for reconciliation and unity, mutual care of believers and settlement of controversies about faith and discipline. Correspondence between Christian communities and local churches, mutual visits, common celebrations of the Eucharist and election of bishops were other factors contributing to the process of conciliarity. According to Sabev, conciliarity should be distinguished from the catholicity of the church (Sabev 1993:263). Sobornost rather emphasises catholicity as harmony of truth and life achieved by the union of each with all, and conciliarity as the principle and expression of the inner catholicity of the body of Christ, as the consensus of faith held by the whole people of God. The term sobornost has no adequate equivalent in any widely used international language. Such suggested translations as 'conciliarity' and 'ecumenicity' take into consideration only part of its meaning, and to do justice to the full wealth of the term would require several other nouns: catholicity, synodality, togetherness, communion, collegiality, collectivity, harmony, concord, mutuality, unanimity, oneness and organic unity (Sabev 1993:263). Sobornost denotes not only the visible union of Christians assembled together but also the continual possibility of such union. Since its inception, the unity of the church as communion has found its best expressions in gathering for prayer, in 'breaking bread' and in facing together doctrinal, disciplinary and ethical problems. The primary goal of councils was the healing of broken koinonia, seeking concord and strengthening unity (p. 266). According to Sabev, modern ecumenical councils have revealed that what is common in the faith and hope of the churches is greater than the differences that separate them. The spirit of sobornost is expressed in common prayers and worship, the affirmation of one baptism, participation in celebrative events of other churches, sharing in joy and suffering, theological dialogue and steps towards convergence and consensus on vital issues and increased commitment to joint projects and other forms of Christian witness (p. 267). According to Sabev, councils are called to be a permanent forum in which divided churches can come together and, through a deeper knowledge of each other, communal life and the holy bond of Christian love, recognise their common belonging to the one, holy, catholic and apostolic church (p. 268).

According to Aram Keshishian of Cilicia, the modern ecumenical movement has created an atmosphere of mutual respect, openness and rapprochement among the churches, which have been deeply divided by history, theology, culture and geography. Although the present ecumenical fellowship contains, explicitly and implicitly, signs and elements of conciliarity, according to Aram, it should not be seen as a conciliar fellowship (Aram 1992:4). With the growth of the ecumenical spirit, isolation gave way to dialogue, conflict to cooperation and suspicion to understanding. The churches began to pray together, to think together and to act together (p. 1). According to Aram, five types of church councils (conseils) exist: The papal councils, representing the Roman Catholic Church; the union councils (the fellowship of those churches that are engaged in church union negotiations); the national and regional councils (the fellowship of those churches which have committed themselves to give institutional expression to their ecumenical collaboration at local and regional levels); the confessional assemblies and conferences (the representative gatherings of Christian world communions, churches which belong to the same tradition); and the pan-Orthodox meetings (representative gatherings of Eastern Orthodox churches) (p. 1). The Oriental Orthodox churches have no regular common meetings. None of these conciliar structures, however, has authority over the whole Christian world (p. 2). The WCC includes almost all the Protestant and Anglican churches as well as the Eastern and Oriental churches. Although the Roman Catholic Church is not yet a member of the WCC, it is a full member of the Commission on Faith and Order and actively participates in the work of the Commission on World Mission and Evangelism, and in a number of other programmes, studies and meetings of the WCC.

In its Toronto statement, the WCC has also made it clear that it does not intend to become a 'super-church' or a substitute for the Una Sancta or an instrument to negotiate unions between churches. It is simply 'a fellowship of churches' (Toronto Statement 2016). Membership in the Council therefore does not imply the mutual recognition of participating churches based on a common ecclesiology, only a common willingness to work together for visible unity (Aram 1992:2). The Orthodox churches have always regarded unity as the raison d'etre of the WCC and, as such, they have insisted that the concern must acquire a top priority on the agenda of the World Council. The initial fear of churches to lose their own identities in the universal, ecumenical fellowship was allayed by the Toronto statement of the WCC, adopted in 1950, shortly after the first WCC assembly. The first Assembly at Amsterdam adopted a resolution on 'the authority of the Council', which read as follows: 
The World Council of Churches is composed of churches which acknowledge Jesus Christ as God and Saviour. They find their unity in him. They do not have to create their unity; it is the gift of God. But they know that it is their duty to make common cause in the search for the expression of that unity in work and in life. The Council desires to serve the churches which are its constituent members as an instrument whereby they may bear witness together to their common allegiance to Jesus Christ, and cooperate in matters requiring united action. But the Council far from desires to usurp any of the functions which already belong to its constituent churches, or to control them, or to legislate for them, and indeed is prevented by its constitution from doing so. Moreover, while earnestly seeking fellowship in thought and action for all its members, the Council disavows any thought of becoming a single unified church structure independent of the churches which have joined in constituting the Council, or a structure dominated by a centralized administrative authority. The purpose of the Council is to express its unity in another way. Unity arises out of the love of God in Jesus Christ, which, binding the constituent churches to him, binds them to one another. It is the earnest desire of the Council that the churches may be bound closer to Christ and therefore closer to one another. In the bond of his love, they will desire continually to pray for one another and to strengthen one another, in worship and in witness, bearing one another's burdens and so fulfilling the law of Christ. (Toronto statement 1950)

The Toronto statement clearly states that the WCC is not and must never become a super-church. It is not the world church. It is not the Una Sancta of which the Creeds speak. Membership in the Council does not in any sense mean that the churches belong to a body that can take decisions for them. Each church retains the constitutional right to ratify or to reject utterances or actions of the Council. The authority of the Council consists only in the weight which it carries with the churches by its own wisdom (Toronto Statement 1950). The purpose of the WCC is not to negotiate unions between churches, which can only be done by the churches themselves acting on their own initiative, but to bring the churches into living contact with each other and to promote the study and discussion of the issues of Church unity. It remains the right and duty of each church to draw from its ecumenical experience such consequences as it feels bound to do on the basis of its own convictions (Toronto Statement 1950). The Toronto statement furthermore stresses that the Council therefore will not press churches into decisions concerning union with other churches:

There is room and space in the World Council for the ecclesiology of every church which is ready to participate in the ecumenical conversation and which takes its stand on the basis of the Council, which is a fellowship of churches which accept our Lord Jesus Christ as God and Saviour. Membership in the World Council does not imply the acceptance of a specific doctrine concerning the nature of Church unity. The Council stands for Church unity, but it does not mean full consensus in the realm of doctrine. (Toronto Statement 1950)

The following assumptions of the Toronto Statement underlie the ecclesiology of the WCC and the ecclesiological implications of its membership (Toronto Statement 1950):
1. The member churches of the Council believe that conversation, cooperation and common witness of the churches must be based on the common recognition that Christ is the Divine Head of the Body. The fact of Christ's headship over his people compels all those who acknowledge him to enter into real and close relationships with each other - even though they differ in many important points.

2. The member churches of the World Council believe on the basis of the New Testament that the Church of Christ is one.

3. The member churches recognise that the membership of the Church of Christ is more inclusive than the membership of their own church body. They seek, therefore, to enter into living contact with those outside their own ranks who confess the Lordship of Christ.

4. The member churches of the World Council consider the relationship of other churches to the Holy Catholic Church which the Creeds profess as a subject for mutual consideration. Nevertheless, membership does not imply that each church must regard the other member churches as churches in the true and full sense of the word.

5. The member churches of the World Council recognise in other churches elements of the true Church. They consider that this mutual recognition obliges them to enter into a serious conversation with each other in the hope that these elements of truth will lead to the recognition of the full truth and to unity based on the full truth.

6. The member churches of the Council are willing to consult together in seeking to learn of the Lord Jesus Christ what witness he would have them bear to the world in his name.

7. A further practical implication of common membership in the World Council is that the member churches should recognise their solidarity with each other, render assistance to each other in case of need and refrain from such actions as are incompatible with brotherly relationship.

8. The member churches enter into spiritual relationships through which they seek to learn from each other and to give help to each other in order that the Body of Christ may be built up and that the life of the churches may be renewed.

The WCC General Assembly held in Uppsala and Nairobi made a sharp distinction between the inter-confessional assemblies and the genuinely universal council. Uppsala described this distinction in these words: 'Some real experience of universality is provided by establishing regional and international confessional fellowships, but such experiences of universality are inevitably partial' (World Council of Churches 1968:17, 29). Furthermore, The Uppsala Report accentuates that the ecumenical movement helps to enlarge this experience of universality, and its regional councils and its World Council should be regarded as a transitional opportunity for eventually actualising a truly universal, ecumenical, conciliar form of common life and witness. The Uppsala proposal built on a study of the Faith and Order commission on "The Importance of the Conciliar 
Process in the Ancient Church for the Ecumenical Movement". According to Konrad Raiser, general secretary of the WCC, the outcome of this study was that conciliarity must be seen as a basic structure in the life of the church, with constantly changing forms of expression in different periods of history (Raiser 1997:205). Uppsala concentrated on restoring an awareness of conciliarity and conciliar forms of life and action at all levels in the church.

According to Aram, these councils (conseils), local, regional and worldwide, can therefore be seen as a transitional opportunity and foretaste on the way to true conciliar fellowship and can be rightly regarded as pre-conciliar gatherings, a fellowship of churches (Aram 1992:4). Aram sees the goal of the ecumenical movement not as the convening of a universal council but rather as the restoration of conciliar fellowship. There are, according to Aram, four basic elements in these two different descriptions of conciliar fellowship that ought to be taken into consideration:

1. First, conciliar fellowship is the full communion of local churches which is realised through the confession of the same faith, sharing in the same Eucharist and the acceptance of the same sacraments and ministry.

2. Second, conciliar fellowship is the communion of local churches, which may hold assemblies of authorised representatives of the local churches.

3. Third, conciliar fellowship is a way forward and a goal, that is, both a continuing and growing process and at the same time an eschatological reality.

4. Fourth, for the Roman Catholic Church, the communion with the Church of Rome and the pope is a precondition for any conciliar fellowship (Aram 1992:6).

According to Aram, the first three points can be regarded as convergent points among the churches. The last point, namely the communion with the Church of Rome and the pope as a precondition for any conciliar fellowship, remains a major issue in ecumenical dialogue (Aram 1992:6).

\section{Receptive Ecumenism}

In the recent years, a shift in the understanding of ecumenism and in methodology has taken place. Receptive Ecumenism emerged in Catholic circles as one of these new methodologies. An international colloquium had been held at Ushaw College near Durham in 2006. Members of the staff of the Department of Theology and Religion at the Durham University and of St Cuthbert's Seminary, Ushaw College, UK - in collaboration with colleagues in Australian, European, and North American institutions - have been engaged for a number of years on a research project in Receptive Ecumenism and Catholic Learning. They were testing the idea of ecumenism done from a 'receptive' perspective (Healey 2001; Murray 2008b). The Roman Catholic Diocese of Hexham and Newcastle, the Anglican dioceses of Durham and Newcastle, the Methodist districts of Darlington and Newcastle and the Northern Synod of the United Reformed Church simultaneously embarked on a Regional Comparative Research Study in Receptive Ecumenism and the Local Church. Five key trajectories are being attended to:

1. Authority and governance.

2. Finance (including generation, demand and administration).

3. Strategies for responding to the challenge posed by the declining numbers of clergy.

4. Lay participation in decision making.

5. Lay training.

The book, Receptive Ecumenism and the Call to Catholic Learning, is in part the result of colloquium. According to Cardinal Kasper ecumenists tend to be utopian. By contrast, the approach of the Durham colloquium, and the collection of essays in Receptive Ecumenism and the Call to Catholic Learning, is according to Kasper less continental, less Germanic, more British and more realistic. Kasper emphatically states: 'It takes what might be regarded as the specifically Anglican approach of via media and speaks of an intermediary ecumenical situation. I welcome this assessment and I am grateful for it' (Murray 2008a). According to Timmer, Kasper's words reflect both an honest assessment of the disappointment and frustration felt by many ecumenists over the continuing lack of visible unity in the church and a hopeful expectation that Receptive Ecumenism has something new to offer to the ecumenical enterprise (Timmer 2014:22). Traditionally, ecumenism emphasises the unity of the faithful towards the final goal of theological and ecclesial convergence (p. 20). For example, the Catholic-Lutheran Joint Declaration on the Doctrine of Justification is an example of traditional ecumenism (p. 22).

Receptive Ecumenism, however, accepts a greater degree of difference between Christians and their respective churches (Timmer 2014:23). Instead of focusing on areas of potential convergence between the churches, proponents of Receptive Ecumenism say that ecumenism at the present needs to focus on the individual growth and learning of each church tradition in dialogue with others (p. 20). Receptive Ecumenism is a reassessment of the ecumenical process, in light of the challenges and difficulties faced by ecumenists. The goal of traditional ecumenism, visible unity through theological and ecclesial convergence, is put aside in favour of an ecumenism of mutual enrichment and self-examination (p. 20). Receptive Ecumenism suggests that a better way forward is to more honestly acknowledge the diversity that exists within the Christian community (p. 23). Receptive Ecumenism claims that the uniqueness of each tradition has to be heard at the ecumenical table and that these differences can help strengthen the church. This includes a deepening of mutual understanding and appreciation between the churches, but more fundamentally, Receptive Ecumenism aims at the maturing and growth within each church in the process of real receptive learning between churches (p. 23, 24). Paul Murray calls for an ecumenism of ecclesial learning and even conversion as each church seeks to learn 'what is strong' from another church (p. 23). 
Avery Dulles suggested already in 1980 that greater allowances for a diversity of theologies in ecumenism should be allowed, because a 'confessional neutral theological method' for ecumenism is not satisfactory for Christians with definite ecclesial commitments (Dulles 1980:40-48). Dulles hopes for the ecumenical movement and a realistic acceptance of some of the remaining differences between the churches. Murray claims that receptive ecclesial learning has transformative potential for ecumenism that is actually more important than 'a theorized conclusion in a convergence statement' (Timmer 2014:24). Dulles earlier also emphasised the convergence model. However, he realised later in his life that there were lingering doctrinal differences that simply resisted such convergence. To 'surmount the remaining barriers', he recommends Receptive Ecumenism, or what he calls testimonial ecumenism. This new perspective is not an indictment that former ecumenical efforts were in vain or even ill-informed. According to Timmer, currently Dulles agrees that remaining issues of difference and disunity might better be addressed today from a perspective of mutual enrichment, or what is now more commonly referred to as Receptive Ecumenism. Dulles sees the potential of this ecumenical method, and perhaps especially for Catholics. He says that it has some Catholic support, particularly in Pope John Paul's encyclical Ut Unum Sint, which speaks of ecumenical dialogue as 'an exchange of gifts between the churches'

Several factors and changes are informing and shaping our world in the 21st century. The visible unity of the church has been seen for a very long time as the central goal of the ecumenical movement. The question currently is: How achievable is it? The goal of visible unity seems further away than ever. Therefore, one should take cognisance of the Receptive Ecumenism and Catholic Learning research project, the key thinking that drives it and its core theological, ecclesiological and practical implications. I concur with Avis's observation that although Receptive Ecumenism initially had been a movement of ecclesiological renewal within the Roman Catholic Church, it holds considerable potential for all churches that are engaged in the ecumenical movement and for closer unity. Receptive Ecumenism and traditional theological dialogue are mutually dependent (Avis 2012). Margaret O'Gara argues that ecumenism today should be seen as an exchange of Christian gifts, indicating that everyone has something to share at the ecumenical table (Timmer 2014:27, 206). Receptive Ecumenism therefore identifies distinct gifts that each tradition brings to the ecumenical table (p. 15). Receptive Ecumenism emphasises the hospitality or receptivity that it claims is essential to the ecumenical process (p. 206).

Paul Avis rightly said that Receptive Ecumenism represents a challenge to all the major churches with regard to the way that they view their ecumenical partners and the assumptions that they bring to the table in dialogue. Paul Avis furthermore admits that receptive ecumenism sounds like a tautology. The question is: 'Is not ecumenism "receptive" by definition? Is not an attitude of receptivity basic to all ecumenical engagement?' (Avis 2012:224). Reception is according to Avis the heart of ecumenism. Ecumenical dialogue involves intentional acts, on the part of the participants in the conversation as well as intentional acts of attention, listening, hearing and taking to heart ('read, mark, learn and inwardly digest'). It is therefore a receptive process. Avis's premise is that if ecumenism had not been essentially receptive, the ecumenical movement could not have achieved what it has achieved during the past century. It would not be able to transform the relationship between the major churches from one marked by hostility, fear, suspicion and rivalry to one characterised by friendship, respect and cooperation. Avis laments that apathy, inertia, inactivity, disinterest, inaction and self-interest are ultimately leading to indecision regarding statements of the global ecumenical movement (p. 225).

Paul Murray and others are arguing in Receptive Ecumenism and the Call to Catholic Learning that the contemporary context requires a fresh ecumenical ethic and strategy that moves beyond both post-denominationalism and any overoptimistic aspiration for full agreement in the immediacy (Murray 2008b). Each tradition should instead focus on the self-critical question: 'What can we learn, or receive, with integrity from our various others in order to facilitate our own growth together into deepened communion in Christ and the Spirit?' Thus, Receptive Ecumenism advocates openness to the ideas of others, but without necessarily seeking compromise or convergence (p. 279-301).

The core theological principles of Receptive Ecumenism include among others the following:

1. The churches are called by the Triune God to grow ever more visibly together in order to express this union-inrelation in appropriate structural and sacramental unity.

2. 'Life and Works' ecumenism - doing things together - is vitally necessary but insufficient alone.

3. Authentic Christian ecumenism can never be a matter either of simply bearing with communion-dividing differences or of collapsing and eradicating such differences; it must rather be a matter of so learning from and across such differences that they can with integrity be brought into configured, mutually enriching communion.

4. The primary aim of ecclesial learning is not the promotion of increased mutual understanding and appreciation between traditions but continuing ecclesial conversion, deepening and expanding growth within traditions by receptive learning from and across traditions; the conviction is that pursuing this primary aim will in time move each tradition, with integrity, to a new place and so open up fresh possibilities for overcoming currently communion-dividing differences between traditions; this emphasis on the ecclesial dimension of conversion needs to extend beyond the doctrinal-theoretical to include also the organisational, the structural, the cultural and the broadly practical.

5. Receptive ecumenical learning, when pursued with dynamic integrity, is not about becoming less but about 
becoming more deeply, more richly, more fully, more freely what we already are: about our becoming all that we are called to be; rather than worrying unduly about what others may need to learn, each should take responsibility for their own learning, mindful that 'We cannot change others, we can only change ourselves but doing so can also promote change in others'; with this, receptive ecumenical learning requires a move away from the presupposition of mutuality - 'we'll move if you move' - to the embrace of a certain unilateral willingness to walk the path of ecclesial conversion for the sake of the greater flourishing of one's own tradition and regardless, to some extent, of whether others are currently prepared to do likewise.

6. Exclusively past-oriented views of tradition and associated problem-solving understandings of the ecumenical task and engage also future-oriented understandings of the Christian tradition as all it is and might be relative to the saving purposes of God in Christ and the Spirit should be resisted.

Paul Murray identifies the main question of Receptive Ecumenism as follows: 'What can we learn, or receive, with integrity from our various others in order to facilitate our own growth together into deepened communion in Christ and the Spirit?' The working assumption is that because of these differences, everyone has something to learn from someone who has a different doctrinal viewpoint. This receptivity includes what Murray calls a 'self-critical' attitude, where every dialogue partner is willing to critically engage their own positions and traditions in the light of others (Murray 2009; Timmer 2014:206).

Dulles, recognising the value of former convergence-style ecumenical efforts, suggested that Receptive Ecumenism offers the best potential for further ecumenical progress (Dulles 2007:26). He believes that this would be particularly effective for those theological issues that ecumenism has not been able to conclusively resolve (Dulles 2007:25, 26; Timmer 2014:206, 207). Dulles makes according to Timmer a strong argument in favour of ecumenism, turning away from its assumptions about convergence and instead affirms a deeper sense of unity in diversity (Timmer 2014:208). Receptive Ecumenism asserts that unity might not mean conformity on every issue. Receptive Ecumenism balances the goal of Christian unity with the individuality and distinctiveness of the Christian churches. This means that church or tradition are encouraged in Receptive Ecumenism to draw from their own history, sources of authority, distinctive doctrines and unique practices to speak at the ecumenical table. Dulles (2007) says:

For the Catholic believer this means including the understandings of tradition, liturgy, sacrament, and the primacy of the bishop of Rome. For believers in churches of the Reformation, Dulles suggests that this means including understandings of the authority of the word, the priesthood of all believers, and the particular expressions of the Reformation slogans: Scripture alone, grace alone, Christ alone, faith alone, and to God's glory alone. (p. 208)
The premise of Receptive Ecumenism is that by listening and speaking, each side may grow in insight and understanding, with the goal to obtain what Dulles calls, 'a deeper share in the truth of Christ' (Dulles 2007:208). Receptive Ecumenism acknowledges that each dialogue partner has something to share at the ecumenical table. The ecumenist should be willing to admit that there may be weaknesses in his or her tradition's articulation of doctrine or unintended consequences when that doctrine is lived out. Perhaps, there are shortcomings or oversights that he or she has yet to be made aware of. The ecumenical process is one that will help uncover these deficiencies, if ecumenists are willing to listen and evaluate (Timmer 2014:210).

\section{Transformative Ecumenism}

Radical and fundamental changes in World Christianity have been taking place during the past decades. The centre of gravity of Christianity is shifting from the global North to the global South. The demography of World Christianity has changed substantially from its historical centre in the West to the non-Western regions of the world, where an exponential growth of Christianity especially in Africa and Asia, has taken place. The mega-shift of global Christianity ultimately brought along a shift for mission theory and practice. The context in which the Christian churches of the non-Western world must live and bear witness about their religious, cultural, social, economic and ethnic conditions has fundamentally changed.

Already in 1998, Kim Yong-Bock, President of Hanil University and Theological Seminary in Chonbuk, Korea, alluded that the ecumenical movement, which is the movement of the people of God in the inhabited earth, is in a rapid transition to a radically new world:

We are experiencing great trends that change the present world into a radically different world. And yet we do not have a definitive analytical grasp of these trends and changes of the world today. Yet we have to keep trying to discern even the signs of times, as we live and move together in this world. (Yong-Bok 1998)

According to Kim Yong-Bok, the framework of civil society is to be considered a way to open a new horizon for ecumenical social thought and involvement from our Christian faith perspective. His premise is that the ecumenical social thought has also been in transition from the context of the liberal society to the challenge of the socialist society and, then, to the Cold War context, and then to the post-Cold War situation. His presumption is that the ecumenical movement articulated as social middle axiom the idea of free society; the idea of responsible society; the idea of just, participatory and sustainable society; and then the idea of justice, peace and integrity of creation. These ideas should be interpreted in a radically new way in the new global situation, according to Yong-Bok (1998).

European Protestantism was a main pillar of the 20th century ecumenical movement in general and the WCC in particular. 
The decline of European Protestantism and the growth of Christianity in the south will have a big impact on the form and future of global Christianity. According to Kobia (2006), the European Protestants have been the backbone of the ecumenical movement:

They are the ones who were the driving forces behind the creation of WCC and many other ecumenical bodies. They are the primary funders of the WCC and other conciliar ecumenical organisations. But Protestantism in Europe is changing: the number of church members is declining, the influence vis-à-vis the state seems to be decreasing, and financial arrangements are changing. (p. 1)

Furthermore, Kobia admitted that the ecclesial landscape changed significantly during the course of time from the conception of the WCC. At the dawn of the 21st century, some of the Pentecostal and Evangelical communities which, for a long time, had adopted an anti-ecumenical stance increasingly became open to ecumenical dialogue. The emphasis fell in the 20th century on engagement and dialogue. According to Kobia (2006:1), life-centred vision will inevitably be a key component of ecumenism in the 21st century. One major challenge facing the ecumenical movement is the need to develop a life-centred understanding of the oikoumene, which embraces all of God's creation.

Transformative Ecumenism can be seen as a life-centred understanding of the oikoumene. This new understanding of ecumenism will bring transformative spirituality and mission to the heart of the ecumenical movement (Keum 2008). Transformative spirituality in mission can be considered as a new vision for the ecumenical movement. According to Maria Aránzuza Aguado, a growing awareness has been perceived in the past few years regarding spirituality as a basic pillar in the journey towards unity. Consequently, spirituality will in the future be one of the main elements in ecumenical education. Her premise is that transformative spirituality in mission can be considered as a new vision for the ecumenical movement (Aguado 2009).

During July 2012, a group of Korean ecumenical theologians, activists and pastors who have been deeply involved in the local and global ecumenical movement and who are deeply committed to building a new, transformative ecumenism in the 21st century organised the Korea Institute for Future Ecumenism (KIFE). The vision of KIFE is to serve the ecumenical movement as a catalyst, as an international think tank, as a global ecumenical network hub and as a theological bridge between Korean ecumenism and ecumenism in the global South. One of the main programmes of the KIFE is organising a series of international theological colloquia over a period of 8 years from Busan (2013) to the next WCC Assembly (2021), which will seek to develop a transformative ecumenical theology and present a projection of the future direction of the global ecumenical movement. The first of the eight colloquiums, which had been attended by a group of selected ecumenical thinkers, activists and theologians, had been held in Seoul, Korea, from 15 to 17 July 2013 and the second colloquium took place in Manila,
Philippines (2014). The third colloquium had been held in Tanzania (2016).

The assumption of KIFE is that the crisis of the ecumenical movement is brought by a prophetic bankruptcy in terms of the movement, an intellectual bankruptcy in terms of the ecumenical spirit and vision and a moral bankruptcy in terms of the leadership (Bujo 1992). Furthermore, the KIFE premise is that the ecumenical movement is no longer strongly rooted in the people and it does not speak a prophetic voice which echoes in the realities of people's struggles for life; the ecumenical movement no longer produces a new and heartbeating vision for the church and the world that are deeply divided and wounded; the ecumenical leadership has suffered from patriarchal, bureaucratic and business-oriented mindedness that lacks the sense of calling and devotion. Yet the world is still suffering from injustice, violence and war. The ecumenical movement should therefore address the dominance of a West-centred paradigm for understanding World Christianity. The presupposition of KIFE is that the ecumenical movement of the future should address issues stemming from the daily struggles of the global South, as well as from critical questions arising from the 21st century, such as universal justice in many dimensions; holistic peace among all living beings, including ecological justice; and life together in conviviality. This demands a global convergence of diverse ecumenical perspectives and experiences of churches in the South as well as in the North, and in the East as well as in the West. It also demands a radical transformation of the ecumenical vision. In addition, the KIFE took note that the global ecumenical movement is also challenged by world religions and the living cultural traditions of the peoples.

Transformative Ecumenism should therefore be an ecumenism that is rooted in the people's struggle for justice and life, an ecumenism that envisions not only the unity of the church like in conciliar ecumenism (Bujo 1992). Rather, Transformative ecumenism focuses on the unity of whole humanity and creation. At the first International Theological Colloquium for Transformative Ecumenism, with the theme Towards Transformative Ecumenism, attention had been given to the factors and changes that are informing and shaping the 21st century as well as the core theological, ecclesiological implication of Transformative Ecumenism. The International Theological Colloquium for Transformative Ecumenism emphasises three areas that will give shape to an alternative and transformative ecumenism that is life-giving and justicecentred:

1. How to rejuvenate movement out of prophetic bankruptcy of ecumenism; the ecumenical movement is no longer strongly rooted in the people and it does not speak a prophetic voice which echoes in the realities of people's struggles for life?

2. How to redefine ecumenism itself out of intellectual bankruptcy of ecumenical spirituality and vision; the ecumenical movement no longer produces a new and heart-beating vision for the church and the world that are deeply divided and wounded. There should be a basic vision and ethos behind transformative ecumenism. 
3. How to reshape the leadership out of moral bankruptcy of ecclesiastical leadership. The ecumenical leadership has suffered from patriarchal, bureaucratic and businessoriented mindedness that lacks the sense of calling and devotion? (Bujo 1992)

The second colloquium, with the theme 'Living out Transformative Ecumenism', held in Manila in 2014, deepened the reflections on how to embody the concepts of transformative ecumenism as an alternative to conciliar ecumenism. The ecumenical movement has traditionally placed a strong emphasis on the conciliar process, reconciling the denominational divisions and rifts among the different Christian traditions (Concept paper of the Manilla 2014). The premise in the second Colloquium was that the 21st century requires that the Christian church look beyond itself. Particularly, the present challenges threatening God's gift of fullness of life for the entire oikoumene require that the ecumenical movement look beyond the traditional patterns and methods of engaging one another and the world in which we are called to be witnesses to God's gift of life, justice and peace. Transformative Ecumenism seeks to intentionally build a strong orientation towards justice and peace while strengthening solidarity with the marginalised groups and the grassroots communities. The second Colloquium provided a road map for how Transformative Ecumenism will serve as an alternative paradigm for the ecumenical movement in the 21st century.

The following objectives of Transformative Ecumenism had been indicated at the Manilla Colloquium:

1. To develop transformative ecumenism as an alternative to conciliar ecumenism.

2. To deepen and consolidate agenda, concept and participation of transformative ecumenism.

3. To critically reflect on the Busan Assembly and to envision the Pilgrimage of Justice and Peace in the light of transformative ecumenism.

4. To strengthen and expand the network of transformative ecumenism (Concept paper of the Manilla 2014).

Seven elements in order to live out Transformative Ecumenism had been identified in the second colloquium:

1. To live out transformative ecumenism is to respond to the call from the margins to seek justice.

2. To live out transformative ecumenism is to live inclusively in solidarity with each other.

3. To live out transformative ecumenism is to actively seek first the kin-dom of God.

4. To live out transformative ecumenism is to empower mutually.

5. To live out transformative ecumenism is to live out the subversive nature of the Gospel.

6. To live out transformative ecumenism is to be rooted in the dynamic spirituality of life.

7. To live out transformative ecumenism is to live and love, struggle and celebrate always hopeful in God's power to transform (Concept paper of the Manilla 2014).
The Third International Theological Colloquium for Transformative Ecumenism with the theme 'Growing Together in Transformative Ecumenism' took place from 11 to 16 January 2016 in Moshi, Tanzania. The aim of the colloquium was to extend the vision of Transformative Ecumenism into the African context in order to rejuvenate movement, to redefine ecumenism and to reshape leadership in the continent. Transformative Ecumenism has to do with:

1. An ecumenism that is rooted in the people's struggle for justice and life.

2. An ecumenism that envisions not only the unity of the church but also the unity of whole humanity and creation.

3. An ecumenism led by passionate and issue-oriented leaders who can clearly stand with the suffering and struggling people (3rd International Theological Colloquium 2016).

The centre of the church's universality is indeed shifting to the global South and Transformative Ecumenism will in future play a major part in rejuvenating, redefining and reshaping ecumenism and in so doing will reform the church at large.

\section{Towards African transformative receptive ecumenism}

African ecumenism also needs to be rejuvenated, redefined and reshaped. I believe that both the notions of Receptive Ecumenism and Transformative Ecumenism can be utilised in order to rejuvenate, redefine and reshape African ecumenism and to move forward to an African transformative receptive ecumenism. Küng rightly deduced that the Catholic Church implanted herself onto the Greek and Latin culture, and then again, though not to the same degree, onto the Germanic and the Slavonic cultures, so that she became, like St. Paul, Greek to the Greeks and barbarian to the barbarians. The question Küng raised is: 'Has she become Bantu to the Bantu, Chinese to the Chinese, Indian to the Indians?' (Küng 1963:248) The context in which the Christian churches in Africa must live and bear witness to their religious, cultural, social, economic and ethnic conditions should become primary research topics of scholars of the continent and should influence the ecumenical discourse globally. An African Transformative Receptive Ecumenism should creatively attend to the quest of the world religions and the living cultural traditions of the African people and the impact thereof on the World Christianity. To combat HIV and/or AIDS is not the only challenge on the Africa continent. Rather, challenges on the continent include rather a broad spectrum of issues ranging from poverty, racism, tribalism, culturalism, modernism, secularism, sexism, human trafficking, health, education, gender-based violence, climate change, economic injustice, corruption, religious conflicts, homophobia, xenophobia, refugees and asylum seekers, statelessness, the challenges of Pentecostal and Charismatic spirituality (wave of new Pentecostalism), the legacy of apartheid, the legacy of the 1994 genocide in Rwanda, the unresolved reconciliation issues in Namibia, the wars in different part of the continent, 
enculturation of Christianity, the growth of African instituted churches (The African Brotherhood Moede 1972), etc. Churches in the global south, especially in Africa, should play a primary role in determining the form and scope of future world Christianity among others to combat injustice, alleviate human suffering, overcome violence and ensure fullness of life for all people (Houtepen 2007). Ecumenical endeavours in Africa should therefore focus on those whose human dignity has been denied by economic, political and social marginalisation. One of the biggest problems of the contemporary ecumenical movement is not the ecumenical winter. It has rather to do with the reception of ecumenism at large. For the most, the reception of ecumenical programmatic work falls short. We are rather seeing a plurality (Latin pluralitatem) of statements on social justice issues issued by the global ecumenical movement.

Cognisance should be taken of the notions of exponents of African Theology, for example, John Mbiti (1986), Kwame Bediako (1990), Lamin Sanneh (1983), Bénézet Bujo (1992), Tinyiko Sam Maluleke (1997), Mercy Amba Oduyoye (1995) and Isabel Phiri (1997), to name a few. The time has come for Africa to drink from her own wells (Maluleke 1996). For example, Mercy Oduyoye highlighted various themes emerging through African religious beliefs and practices ranging from stewardship of the earth, community life, women, the divine right of kings and human wholeness, to making covenants, the power of evil, reconciliation, rites of passage and liturgical practices. According to Oduyoye, because African religious beliefs emphasise the 'common origin of all humanity', they can facilitate one's sense of dignity and human responsibility towards self and others while inspiring people throughout the world to return to 'basic principles of human community and the religious basis of life' (Oduyoye 1979). Already in the 70s Oduyoye argues that African Theology and/or themes equated with Africa have the potential to inform, challenge, deepen and expand Christianity at large. The time has come for African Christian theologians to revisit these and other themes, to draw from its context, empowering myths in African tradition and to integrate their African religious heritage into Christian theology as Mercy Oduyoye suggested. Oduyoye also acknowledges the mutual contributions of both the African religious heritage and the Christian theology and the need to draw upon them equally in a genuine effort to shape for all of humanity including women (Oduyoye 1979:115,116). According to Maluleke, Black and African theologies will have to show more respect for African culture and African traditional religions than to see them merely as preparations for the Christian gospel (Maluleke 1996). Bénézet Bujo in his 1992 work, African theology in its social context, goes as far as to state that Christianity has robbed Africa of many central elements of its culture (1992:9). Bujo (1992-17-18) argues that long before the arrival of Christianity in Africa, African religion recognised God as the source of all life, especially human life. It means most of the tribes of Africa worshipped one God and God alone. Bujo (1992:83) notes that, the African ancestors are in this way forerunners, or images, of the protoAncestor, Jesus Christ. Bujo suggests giving Jesus the title of
'Ancestor Par Excellence' or 'Proto-Ancestor'. (Nyamiti 1984) Bujo uses the theology of ancestors as a starting point for Christology and ecclesiology. The above mentioned assumptions should be taken account for in developing an African Transformative Receptive Ecumenism.

African and Black theologians should explore the commonality of all religions. In most parts of Africa, people from different faiths are living in close proximity without tension with each other. According to Degenaar to ignore differences among cultures and differences within cultures is a refusal to admit fact that each cultural group has its own history and that justice demands that each should be treated accordingly. Multiculturalism refers not only to the coexistence of various cultures but also to cultural differences running across various cultures and being inherent in any distinct cultures. For Degenaar, to be human is to affirm one's humanity by recognising the humanity of others in its infinite variety of content and form (Degenaar 2000:166-169).

An African Transformative Receptive Ecumenism should not focus on differences or on maintaining borders with other cultures. It should rather be open to share values and dialogue. An African Transformative Receptive Ecumenism should recognise socio-cultural identities - such as national, ethnic and tribal identity - while at the same time confirming the unity of the church. According to Degenaar, transculturalism transcends the boundaries of "native cultures' (Degenaar 2000:156). Transculturalism liberates people from 'those symbolic dependencies, ideological addictions, patriotic infatuations that belong to people as members of a certain cultural group' (Epstein 1999). Ecumenical activists and scholars should therefore ask themselves: What can we learn, or receive, with integrity from our various others in order to facilitate our own growth together into deepened communion in Christ and the Spirit? A novel and transformative approach to ecumenism in Africa should take cognisance thereof that the Spirit is already gathering people from many different traditions, communities and even religions to work together for justice and peace. Ecumenists with other Christians and adherents of other faiths and contemporary ideologies should search anew for God and his truth for the church and the world today. In doing so, cognisance should be taken of Küng's notion about a confessionalist ghetto mentality. As Kung rightly said, this situation does not require that 'theology and the Church revert to a private spiritual subjectivity, or take refuge in purely political concerns, or nostalgically long for the Christian society of the past' (Küng 1980). Rather, in a collaborative way, account should be taken of the various traditions and theologies in order to embark on new and practical ways in which a local parish, Christian agency or governance body may carry out transformative ecumenism. The core theological as well as ecclesiological and practical implications of Transformative and Receptive Ecumenism should become the focus of research of scholars in the African continent. 


\section{Conclusion}

Ecumenism has become easily associated with the conciliar model of ecumenism. During the course of time, objections against the conciliar model of ecumenism rose. It seems as if the season for a conciliar model of ecumenism has come too pass. Social movement and/or peoples movement that is issue based and challenges power should rather be the centre of the ecumenical movement. Transformative Ecumenism as well as Receptive Ecumenism can be seen as responding to God's agenda in the world namely to appreciate what can be learnt or received, with integrity from others, to accompany people in their struggle for justice and life and to envision the unity of whole humanity and creation. Transformative Ecumenism challenges the malaise and irrelevance in conciliar ecumenical movement and is deeply rooted in the hunger for ecumenical renewal. An African Transformative Receptive Ecumenism that is inclusive, empowering and life-giving will surely bring about the millennium shift in global Christianity.

\section{Acknowledgements Competing interests}

The author declares that she has no financial or personal relationships which may have inappropriately influenced her in writing this article.

\section{References}

Aguado, M.A., 2009, 'Transformative spirituality and mission: An ecumenical project', International Review of Mission 98(2), 218-231.

Aram, K., 1992, Conciliar fellowship: A common goal, WCC Publications, Geneva.

Aram, I., 2005, Challenges facing the Roman Catholic Church-WCC collaboration. Presentation at the event marking the 40th anniversary of the Joint Working Group between the Roman Catholic Church and the WCC, WCC Publications,
Geneva, viewed 17 February 2016, from https://www.oikoumene.org/...wCc/ challenges-facing-the-roman-catholic-church-wcc-

Avis, P., 2012, 'Are we receiving “Receptive Ecumenism"?' Ecclesiology 8, 223-234.

Bediako, K., 1990, Jesus in African Culture: A Ghanaian Perspective, Asempa Publishers, Accra.

Bediako, K., 1996, 'Five theses on the significance of modern African Christianity: A Manifesto', Transformation 13(1), 20-21.

Black, A., 1988, 'The conciliar movement', in J.H. Burns (ed.), The Cambridge history of medieval political thought c.350-c.1450, 588-606, Cambridge University Press, Cambridge.

Brinkman, M.E., 1995, Progress in unity? Fifty years of theology within the world Council of Churches, 1945-1995. A study guide, Peeters, Louvain.

Bujo, B., 1992, African theology in its social context, transl. J. O'Donohue, Concept paper of the Seoul International Theological Colloquium for Transformative Ecumenism 2013, Orbis, Maryknoll, viewed 17 February 2016, from https://www. miraeforum.org/category/Colloquium

Degenaar, J., 2000, 'Multicuturalism: How can the human world live its difference?', in V. Vugt (ed.), The race and reconciliation in South Africa: A multicultural dialogue in comparative perspective, 156-170, Lexington books, New York.

Dulles, A., 1980, 'Ecumenism and theological method', Journal of Ecumenical Studies $17,40-48$.

Dulles, A., 2007, 'Saving Ecumenism from itself', First Things, pp. 1-26.

Eastman, P.E., 1949, 'The Amsterdam Assembly of the World Council of Churches and an International Legal Order', The International Law Quarterly 2(4), 1948-1949, 674-677.

Ecumenical Collaboration at Regional, National and Local Levels, 1975, Secretariat for promoting Christian unity, Vatican, p. 19, viewed 17 February 2016, from nla.gov. promoting Christian unity,

Council of Trent, Ecumenical Council World Heritage Encyclopedia, viewed 17 February 2016, from www.worldheritage.org/articles/Ecumenical_council

Epstein, M.N., 1999, 'From culturology to transculture', in E.E. Berry \& M.N Epstein (eds.), Transcultural experiments: Russian and American models of creative communication, p. 24, St. Martin's Press, New York.
Healey, N.M., 2001, 'Receptive Ecumenism and the call to catholic learning ed. by Paul Murray', International Journal of Systematic Theology 13.4 2001, 480.

Houtepen, A.P.A., 2007, 'Called to be the one church: Ecumenism beyond its Crisis?', Exchange 36, 87-102.

Kasper, W., 2004, That they may all be one: The call to unity today, Burns \& Oates, New York, pp. 1-6.

Kasper, W., 2005, The Ecumenical movement, Presentation at the event marking the 40th anniversary of the Joint Working Group (JWG), between the Roman Catholic Church and the WCC, 18 November 2005, WCC Publications, Geneva.

Kasper, W., 2011, 'May they all be one A vision of Christian unity for the next generation', Didaskalia xli, 2, 13.

Keum, J., 2008, 'Editorial', International Review of Mission 97(384/385), 5.

Kim, Y.B., 1998, Civil Society: Unity and Oikos (the House of God), viewed 17 February 2016, from https://www.religion-online.org/showarticle.asp?title

Kim, Y.B., (ed), 2014, Concept paper of the Manilla International Theological Colloquium for Transformative Ecumenism 2014, viewed 17 February 2016, from https://www.miraeforum.org/category/Colloquium

Kim, Y.B., (ed), 2016, Growing Together in Transformative Ecumenism, 3rd International Theological Colloquium for Transformative Ecumenism, Lutheran Hotel, Moshi, 1-5.

Kobia, S., 2005, Challenges facing the ecumenical movement in the 21st century, viewed 17 February 2016, from https://www.oikoumene.org/.../wcc.../ ecumenical-movement...century/.../challenges-fa

Küng, H., 1963, The council in action, Theological Reflection on the Second Vatican Council, New York, Sheed \& Ward, p.51.

Küng, H., 1980, 'Toward a New Consensus in Catholic (and Ecumenical) Theology in Swidler, Leonard. (ed.) 1980. Consensus in Theology/ A Dialogue with Hans Küng and Edward Schillebeeckx', Journal of Ecumenical Studies 17(1), pp. 1-15.

New World Encyclopedia contributors, Marsilius of Padua - New World Encyclopedia, viewed 17 February 2016, from http://www.newworldencyclopedia.org/p/index. php?title=Marsilius_of_Padua\&oldid $=984476$

Maluleke, T.S., n.d., 'Theological Interest in African Independent Churches and Other Grass-Root Communities in South Africa', pp. 18-48.

Maluleke, T.S., n.d., 'Black and African theologies in the new world order a time to drink from our own wells', Journal of Theology for Southern Africa 96, 3-19.

Maluleke, T.S., 1997, 'Half a century of African Christian theologies elements of the emerging agenda for the twenty-first century', Journal of Theology for Southern Africa 99, 4-23.

Mbiti, J.S., 1986, Bible and theology in African Christianity, Oxford University Press, Nairobi.

Moede, G.F., 1972, The African Brotherhood Church, The Ecumenical Review, 24 (2), 145-159.

Moss, V., 2015, The Conciliar Movement, viewed 17 February 2016, from https:// www.academia.edu/18142744/THE_CONCILIAR_MOVEMENT

Murray P.D., 2008a, 'Receptive Ecumenism and Catholic Learning: Establishing the Agenda', Receptive ecumenism and the call to Catholic learning, in P. Murray (ed.), pp. 2-30, Oxford University Press, Oxford.

Murray, P.D., 2008b, 'Receptive ecumenism and catholic learning: Establishing the agenda by', International Journal for the Study of the Christian Church 7(4), 279-301, https://doi.org/10.1080/14742250701725785

Murray, P., 2009, 'Faith and order \& receptive ecumenism', One in Christ 43(2): 194.

Nyamiti, C., 1984, Christ as our ancestor: Christology from an African perspective, Mambo Press, Gweru.

Oduyoye, M.A., 1979, 'The value of African religious beliefs and practices for Christian theology', in K. Appiah-Kubi \& S. Torres (eds.), African theology en route: Papers from the Pan-African conference of Third World theologians, December 17-23, 1977, Accra, Ghana, (pp. 109-116), Orbis Books, Maryknoll, NY.

Oduyoye, M.A., 1995, 'Christianity and African culture', International Review of Mission 84(332/333), 77-90.

Phiri, I.A., 1997, Presbyterianism and patriarchy: Religious experience of Chewa women in Central Malawi, Kachere Series, Zomba.

Raiser, K., 1997, To be the Church: Challenges and hopes for a new millennium, World Council of Churches, Geneva.

Sabev, T., 1993, 'The nature and mission of councils in the light of the theology of Sobomost', The Ecumenical Review 45(3), 261-270.

Sanneh, L., 1983, West African Christianity. The Religious Impact, C. Hurst, London.

Timmer, S., 2014, 'Receptive ecumenism and justification: Roman catholic and reformed doctrine in contemporary context', Dissertations (2009), Paper 362, viewed 17 February 2016, from http://epublications.marquette.edu/ dissertations_mu/362

1964, Unitatis Redintegratio ("Restoration of Unity"), Second Vatican Council's Decree on Ecumenism, promulgated by Pope Paul VI on November 21, viewed 17 February 2016, from www.vatican.va/archive/.../vat-ii decree_19641121 unitatis-redintegratio_en.html

1995, Ut Unum Sint ("That they may be one"), an encyclical by Pope John Paul II of May 25, on commitment to ecumenism, viewed 17 February 2016, from w2 vatican.va/content/john-paul-ii/en/.../hf_jp-ii_enc_25051995_ut-unum-sint.html

1950, 'The church, the churches and the World Council of Churches: The Ecclesiological Significance of the World Council of Churches', Ecumenical Chronicle, October 1950, 47-53. 
Vischer, L., 1972, 'Christian councils - Instruments of ecclesial communion', One in Christ, 8(2), 140 .

Wainwright, G., 1977, 'Conciliarity and Eucharist', in Churches in Conciliar Fellowship? European Churches, Report of a Consultation at Sofia, Conference, Bulgaria, October, Geneva.

World Council of Churches, 1968, The Uppsala Report, World Council of Churches, Geneva.
World Council of Churches, 1976, Breaking Barriers, official report of the fifth assembly of the WCC, Nairobi, 1975, D.M. Paton (ed.), London, SPCK, and Grand Rapids, Eerdmans.

World Council of Churches General Assembly in Busan, 2013, Ecumenica Conversations, viewed 17 February 2016, from https://www.oikoumene.org/.../ ecumenical-conversations-repor 